\title{
Hudební divadlo Waltera Felsensteina a jeho domácí recepce
}

\section{Walter Felsenstein's Music Theatre and His Czech Reception}

Šárka Havlíčková Kysová / 66521@mail.muni.cz

Department of Theatre Studies, Masaryk University, Brno, CZ

Helena Spurná / helena.spurna@upol.cz

The Department of Theatre, Film and Media Studies, Palacký University, Olomouc, CZ

\begin{abstract}
The study deals with the Czech reception of Felsenstein's work, which gained from the 50s a priviledged position over the countries of the so-called Eastern Bloc. Summarizing history of the Komische Oper's visiting performances in Prague as well as Felsenstein's attendance in Czechoslovakia, the contribution brings some arguments for Walter Felsenstein's impact on the Czech operatic theatre. This can be primarily seen in the theoretical considerations of the director Miloš Wasserbauer. The study also includes a few examples of Felsenstein's cooperation with some outstanding Czech music artists - conductors as well as singers.
\end{abstract}

\section{Keywords}

Walter Felsenstein, Komische Oper Berlin, music theatre, Czech opera theatre 
Úvodem našeho příspěvku, kterým chceme připomenout zřídka reflektované téma domácí muzikologie a teatrologie, budiž řečeno, že hudební divadlo Waltera Felsensteina (1901-1975) patří v českém prostředí k málo vyjasněným operně režijním koncepcím. Není se čemu divit. Před rokem 1989 podléhal obraz režiséra a jeho tvorby oficiální kulturní politice, která v něm našla vhodný nástroj k šíření principů, jimiž se měla řídit umělecká praxe všech divadel východního bloku. Po změně společensko-politické situace a s tím, jak se české operní divadlo v devadesátých letech otevíralo novým inscenačním proudům ze západoevropských scén, jako by Felsenstein, až příliš zatížený zjednodušujícími výklady minulé doby, přestal pro přítomnost existovat.

O Felsensteinovi existuje v češtině dosud jediná biografická práce, jejíž forma je spíše popularizační a která je způsobem výkladu notně poplatná období vzniku. Karel V. Burian, autor publikace Walter Felsenstein (1979), se zjevně inspiroval u Siegfrieda Melchingera a knihy Musiktheater z roku $1961,{ }^{1}$ na kterou hojně odkazuje s ohledem na její vydání ve slovenštině o tři roky později. Oba autoři - jak Melchinger, tak Burian - zvolili obdobnou strukturaci biografických dat, které zanikají v množství digresí a asociativních vstupů. V Burianově knize převládá duch subjektivní dojmologie, který se „vznáší“ i nad částmi, v nichž je vysvětlován Felsensteinův koncept hudebního divadla. V tomto ohledu se jako přínosnější ukazuje Melchingerova kniha, jejíž stěžejní část tvoří Felsensteinovy úvahy a rozhovory o opeře, které vykazují vysokou míru autentičnosti. Za Felsensteinova života přispívali $\mathrm{k}$ obeznámenosti $\mathrm{s}$ jeho uměleckou osobností a $\mathrm{s}$ tím, co v dobovém operním divadle představoval, také někteří recenzenti. Zejména hudební publicistka Jarmila Brožovská činnost Waltera Felsensteina reflektovala už v 50. letech. Když v roce 1959 zhlédla přímo v Berlíně inscenaci Othella, napsala o ní a o Felsensteinovu hudebním divadle obsáhlý referát. ${ }^{2}$ U př́ležitosti hostování Komické opery v Praze v roce 1956 a 1962 poskytl Felsenstein několik rozhovorů, v nichž neúnavně principy své tvorby vysvětloval. Krátce po vydání v Německu se i na pultech českých knihkupectví objevil almanach Die Komische Oper 1947-1954, rekapitulující dosavadní činnost scény ve formě článků různých osobností i bohaté fotodokumentace. ${ }^{3}$ Tím ale výčet domácích zdrojů k poznání režisérova působení v oblasti opery de facto končí, přičemž po roce 1989 už k němu nikdo nic podstatného nedodal.

O to důležitější je fakt, že v samotném Německu je Felsensteinovo myšlení o opeře spolu s jeho inscenačním odkazem v poslední době problematizováno. Po řadě odborných prací, udržujících vžitou a zdánlivě neotřesitelnou představu slavného německého režiséra jako strůjce a realizátora tzv. realistického hudebního divadla, vyšla v roce 2015 kniha Borise Kehrmanna (1963) Vom Expressionismus zum verordneten „Realistischen Musiktheater“ (Walter Felsenstein - Eine dokumentarische Biographie 1901 bis 1951). A tato více než 1300 stránková publikace, jež získala v mezinárodní anketě kritiků prestižního německého časopisu Opernwelt „Kniha roku“ 2015 druhé místo, felsensteinovským mýtem notně za-

1 Walter Felsenstein je v knize, kterou vydalo nakladatelství Carl Schünemann Bremen, uveden jako spoluautor.

2 BROŽOVSKÁ, Jarmila. Zápas o pravdu v opeře. In Divadlo, roč. 10 (1959), č. 10, s. 780-788.

3 OTTO, Werner (red.). Die Komische Oper 1947-1954. Henschel, Berlin 1954. 


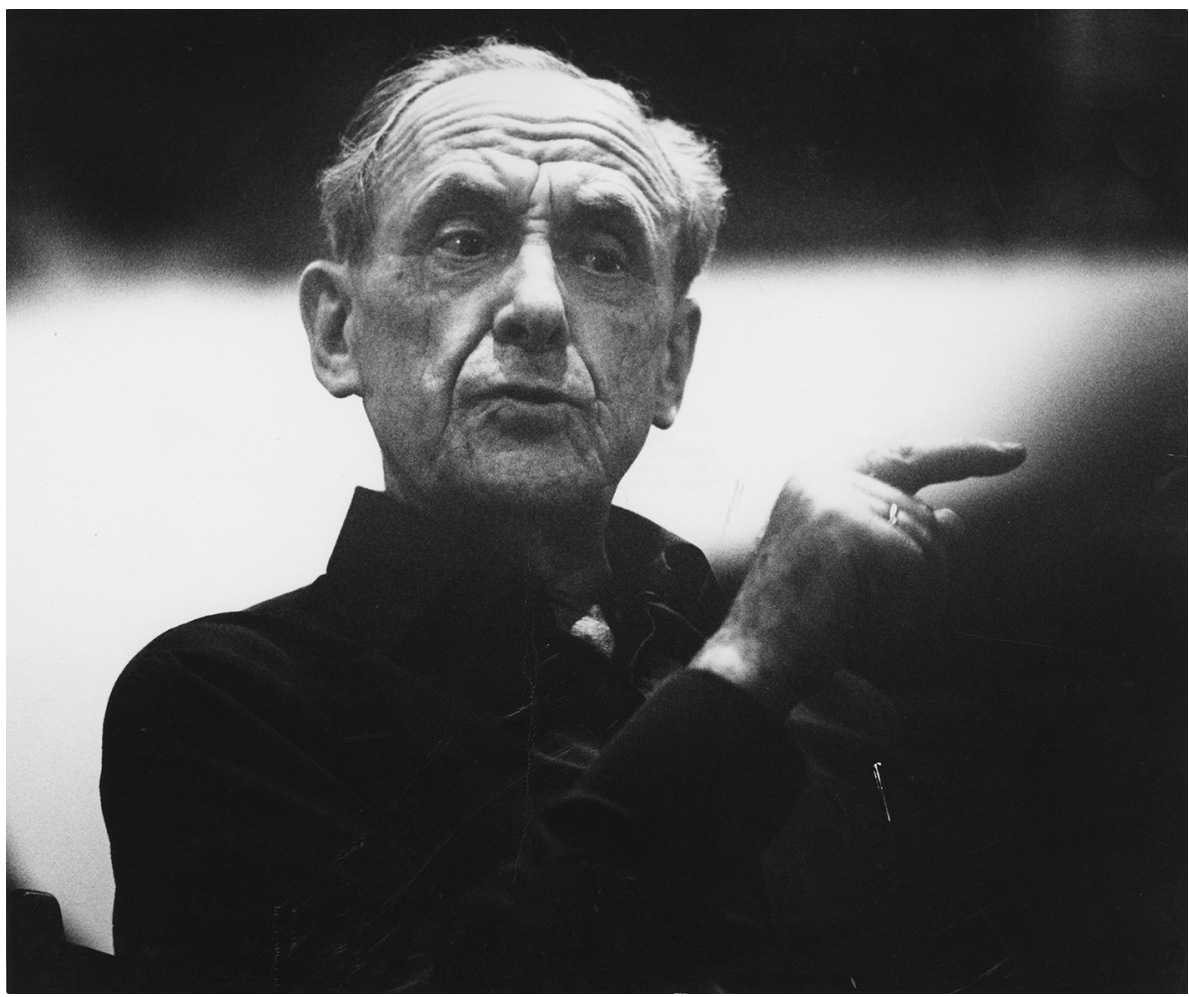

Obr. 1 Walter Felsenstein, 1973. Zdroj: Akademie der Künste, Berlin. Walter-Felsenstein-Archiv, sign. 1695_08. Foto: Maria Steinfeldt.

cloumala. ${ }^{4}$ Kritické přezkoumání veškeré dokumentace k Felsensteinovu životu a dílu, která se v minulosti nejednou stala předmětem ideologicky motivovaných zásahů, odhalilo řadu pomýlených závěrů, které v odkazu Waltera Felsensteina panují. Po důkladném přečtení této odborné práce už nelze tvrdit, že to byl sám režisér, který spojil pojem Musiktheater s přídomkem „realistický“. Dobové prameny ukazují, že šlo o nálepku východoněmeckých stranických funkcionářů, která vznikla jako jeden z produktů transformace kultury v nově vzniklém státě pod egidou socialistického realismu. Jak však Kehrmann ve své knize rovněž konstatuje, s tímto nařizeným „realistickým hudebním divadlem “ dokázal Felsenstein své vlastní umělecké plány bezebytku naplnit a obratně, s pragmatismem sobě vlastním jej využít v zájmu Komické opery, která si záhy získala status výstavní skříně východoněmecké kultury. ${ }^{5}$ Debaty o realismu jakožto uměleckém stylu, který se i na

4 Publikaci Borise Kehrmanna se podrobně věnujeme ve studii Realismus hudebního divadla Waltera Felsensteina - pravda, nebo mýtus?, v níž kromě rekapitulace autorových stěžejních tezí přinášíme také podrobný životopis Waltera Felsensteina a na základě uveřejněných statí základní charakteristiku jeho koncepce hudebního divadla. Srov. HAVLÍČKOVÁ KYSOVÁ, Šárka a Helena SPURNÁ. Realismus hudebního divadla Waltera Felsensteina - pravda, nebo mýtus? Theatralia, roč. 20 (2017), č. 1, s. 88-121.

5 Srov. KEHRMANN, Boris. Vom Expressionismus zum verordneten „Realistischen Musiktheater“. Walter Felsenstein 
jevišti projevoval jako věrná nápodoba skutečnosti, jej však příliš nezajímaly a nejednou se vůči tomuto pojetí kriticky vymezoval. Zaštitoval se sice pojmy jako Glaubwürdigkeit (věrohodnost) nebo Wahrheit (pravdivost). Jeho cílem však bylo u zpěváků dosáhnout takového hereckého výrazu, který vzbuzoval dojem obsahové pravdivosti a přesvědčivosti, odehrávající se v ohraničeném světě jevištni skutečnosti. „Hudebni divadlo nastává tehdy, když se hudebni děj se zpívajicimi osobami stane divadelni realitou bezvýhradné věrohodnosti," ${ }^{6}$ zdůraznil v roce $1951 \mathrm{v}$ referátu Je hudebni divadlo záležitostí lidu? (Ist das Musiktheater eine Angelegenheit des Volkes?). ${ }^{7} \mathrm{~V}$ neustálém uvědomování si divadla jako umělé reality a přiznáváním „ireálné“ podstaty opery, vyplývající ze zpěvu jako vyjadřovacího prostředku, Felsenstein zdůrazňoval, že realismus nesmí být zaměňován s jakoukoli formou naturalismu. Proto ani rozlišování realismu a formalismu nemá pro uměleckou praxi prý žádnou platnost. ${ }^{8}$ „Označeni realismus se vztahuje na obsah [...] lidského vyjádření, nikoli na styl. Tudiž $i$ představení, jež je realizováno ve stylizované dekoraci, může být plně realistické. "O9 Oficiální doktríně odporovala nejen tato slova, která pronesl roku 1971 v dokumentu východoněmecké režisérky Gitty Nickel Walter Felsenstein. ${ }^{10}$ Podobných výroků, v nichž stereotypní náhled na realismus a vyprázdněné používání pojmu podroboval kritické analýze, vyřkl Felsenstein od padesátých let celou řadu. V době, kdy zahajoval činnost Komické opery (1947), měl za sebou dvacetileté působení v profesi režiséra řady německých scén. Ve svých inscenacích se vždy hlásil k expresionistickému stylu, který ještě v roce 1971 považoval za „nejdůležitějši a nejuliunějši umělecký směr 20. stoletî. ${ }^{11}$ Nejvíce jej prý oslovili režiséři Alexandr Tairov, Leopold Jessner, Jürgen Fehling, Peter Brook a Giorgio Strehler. ${ }^{12}$ Nabízí se samozřejmě otázka, jak se s poetikou těchto tvůrců srovnává koncept divadla v duchu realistického, potažmo socialisticko-realistického stylu.

Proklamace umělce jistě nemohou být dostatečným podkladem pro stylovou charakteristiku díla. Dosud obecně přijímanou klasifikaci Felsensteinova divadelního stylu však problematizuje samotná inscenační tvorba. Neexistence nejdůležitějšího pramenu v podobě představení, jež tento režisér v letech 1947-1975 vytvořil v Komické opeře, hodnocení ovšem notně komplikuje. Z divadelních představení se dochovaly pouze záznamy úryvků a zpravodajské šoty; později vzniklé operní filmy, které v roce 2009 vyšly jako DVD edice, ${ }^{13}$ nelze považovat za věrohodný obraz Felsensteinových jevištních děl.

- Eine dokumentarische Biographie 1901 bis 1951. [Dresdner Schriften zur Musik. Hochschule für Musik Carl Maria von Weber Dresden, hg. von Matthias Herrmann, Bd. 3, 2 Teile]. Tactum, Marburg 2015, s. 64-69.

6 „Musiktheater ist, wenn eine musikalische Handlung mit singenden Menschen zur theatralischen Realität und vorbehaltlosen Glaubhaftigkeit wird.“

7 Srov. FELSENSTEIN, Walter, Götz FRIEDRICH a Joachim HERZ. Musiktheater. Beiträge zur Methodik und zu Inszenierungs-Konzeptionen (hg. von Stephan Stompor). Philipp Reclam, Leipzig 1970, s. 29.

8 KEHRMANN, op. cit., s. 57.

9 „Die Bezeichnung Realismus bezieht sich ja auf den Inhalt [...] einer menschlichen Äußerung und nicht auf den Stil. Auch eine in stilisierten Dekorationen stattfindende Aufführung kann völlig realistisch sein."

10 Cit. dle KEHRMANN, op. cit., s. 231.

11 Srov. FELSENSTEIN, Walter. Theater. Gespräche, Briefe, Dokumente (hg. von Ilse Kobán). Edition Hentrich, Berlin 1991, s. 82; cit. dle KEHRMANN, op. cit., s. 203.

12 Srov. KEHRMANN, op. cit., s. 54.

13 Srov. Walter Felsenstein Edition (12 DVDs), Arthaus Musik GmbH, 2009. 
(A to bez ohledu na jejich nezpochybnitelnou poznávací hodnotu a význam z hlediska historické dokumentace.)

O to více to platí pro záznamy, které netočil v autentickém prostředí jeviště, nýbrž ve filmovém studiu: viz Othello, Hoffmannovy povidky, Rytî́ Modrovous a Liška Bystrouška. Důležitý konfrontační materiál poskytují recenze na uvedení v Komické opeře, z nichž se dá získat překvapivě rozmanitý vzorek dobové recepce Felsensteinova inscenačního stylu. Lze z nich dovodit, že za realistické byly považovány inscenace Othella nebo Lišky Bystroušky. Avšak offenbachovské inscenace (Hoffmannovy povídky a Rytiř Modrovous), jevištní ztvárnění Orffovy Chytracky nebo Brittenova Snu noci svatojánské nemohly zapřít prvky stylizace, jež se tu více, tu méně projevila ve výpravě i v herectví. Př́zračnost a fantasknost jevištního dění v Hoffmannových povidkách, kterou podtrhávala výrazná práce se světlem, grotesknost kostýmů, karikatura a herecká nadsázka v provedení Modrovouse v těchto atributech offenbachovských představení byla kontinuita s Felsensteinovou předválečnou expresionistickou tvorbou více než zřejmá. Ve filmovém zpracování však z nich mnoho nezbylo. Vyplyne to ze srovnání s dochovanými krátkými ukázkami z původních představení Komické opery, které vyšly v rámci zmíněné edice Felsensteinových operních filmů. Stojí za zmínku, že Kehrmann zpochybňuje jako realistický dokonce i způsob herectví v inscenaci Liška Bystrouška. Ta totiž bývá považována za nejvýrazněǰši příklad Felsensteinovy iluzivní jevištní poetiky. Lze pokládat za realistické, ptá se Kehrmann, když představiteli zviŕete přiřadil Felsenstein lidskou postavu, charakterizovanou stejným gestem? Divák měl za maskami zvírat stále vidět zpěváky, kteří tato zviŕăata představují, a identifikovat $\mathrm{v}$ nich lidské postavy př́iběhu. Tak Werner Enders hrál nejen ustrašeného Rechtora, ale také bitého psa Lapáka, Josef Burgwinkel představoval z vesnice vyháněného Faráře a rovněž Jezevce, vyhnaného z nory, Adelheid Müller pak představovala bigotní ženu revírníkovu a také bigotní sovu. Irmgard Arnold jako Liška se zrcadlila silnou touhou po erotické svobodě v Terynce Helgy Naujok, Georg Baumgartner jako Lišák v roli Harašty (Herbert Rössler) a liščata v revírníkově synu a jeho kamarádech. Za chováním zviŕă tak divák mohl neustále vnímat zcizený obraz lidského chování s jeho typickými znaky. ${ }^{14} \mathrm{~V}$ návaznosti na Kehrmannovu připomínku bychom se mohli ptát, co lze považovat za realistické kupř. na obsazení Oberona a Titanie v Brittenově Snu noci svatojánské černošskými zpěváky. Nešlo o divadelní znak, který měl podtrhnout odlišnost světa duchů od ř́še lidí? Důsledně realistická výprava Lišky Bystroušky byla spíše výjimkou, v ostatních inscenacích dával Felsenstein přednost stř́zlivému náznaku prostředí děje. Využíval také prvky (kupř. zvýrazněný portál, hrací pódia nebo okna a dveře stojící uprostřed prázdného prostoru), jimiž udržoval dojem divadla jako umělé reality.

$\mathrm{Z}$ výše řečeného vyplývá, že klasifikace Felsensteinova inscenačního stylu není jednoduchá. Nahlédneme-li na tvorbu tohoto režiséra jako na odnož realismu 19. století, ocitáme se před otázkami kardinálního významu. Naše uvažování o Felsensteinově realismu z hlediska uměleckého stylu může začít u relevantních pochybností, co konkrétního vlastně víme o podobě realismu $\mathrm{v}$ divadle 19. století. Víme, jak přesně vypadalo realistické herectví v praxi, do jaké míry se herec dokázal „identifikovat“ se svou postavou?

14 Srov. KEHRMANN, op. cit., s. 53-54. 
Máme jasnou představu o tom, co konkrétně z realismu přešlo do pozdějších období? Jsme schopni důvěryhodně popsat, $\mathrm{k}$ jakým proměnám původního stylu došlo? Těžko si představit, že navzdory veškeré snaze by bylo možné zopakovat realismus ve všech jeho někdejších projevech v době vyznačující se výrazně jinými sociálně kulturními a estetickými parametry. Proto také když Felsenstein hovořil o „pravdivosti“ jevištního vyjádření díla, pak s vědomím nezbytné konfrontace každého historického uměleckého artefaktu se „zde“ a „nyni“ pozdějších interpretů, jejichž poznání reality se s vnímáním v době, kdy autor dílo napsal, zákonitě zcela neshoduje. A z toho důvodu mohl i Heinz Josef Herbort v eseji o dřívější Felsensteinově inscenaci Kouzelné flétny (1954) napsat, že „Tamino ukazuje v roce 1967 zprisob chováni, jež je pravdivé právě v této době a to neni - můžeme ř́ci: bohužel, stejně tak ale i bohudik - skutečnost, realita roku 1791. Tu už nelze realizovat. Realistické hudebni divadlo - bez toho, že bychom chtèli zahladit výčitku, budiž řěéno, že nadmíru ceněné - je pozoruhodným anachronismem a jeho systém se projevuje vlastně jako jakýsi terminologický hermafrodit: dovolává se fenoménu reality, sama tato realita ale reálná neni. " ${ }^{15} \mathrm{~V}$ souvislosti s oblastí divadla, k níž se vztahujeme, se nabízejí další otázky, zejména pak tato: můžeme $\mathrm{v}$ intencích realistického stylu vůbec uvažovat $\mathrm{u}$ tak vysoce stylizovaného žánru, jakým je opera? Takto se ptal sám Felsenstein svými relativizujícími výroky o realistickém hudebním divadle.

Jestliže chceme zhodnotit Felsensteinův realismus v inscenování opery tak, jak pojem chápal on sám, tedy v obecnější rovině „věrného“ přetlumočení skladatelova záměru jevištními prostředky, musíme rozlišovat mezi dobou vzniku jeho inscenací a perspektivou vývoje $\mathrm{v}$ evropském divadle uplynulých padesáti let. Ve světle převažující praxe tradičního operního inscenování včetně konvencí v operním herectví se Felsensteinova snaha nutně musela dobovému publiku jevit coby projev realismu (v širším slova smyslu). Jako inovativní je třeba vnímat přiblížení opery činohře, podřízení všeho, co se na scéně odehrává, hodnověrnému ztvárnění hudebně dramatické situace. $\mathrm{S}$ tím souvisí posílení role režiséra v opeře, což se projevovalo pro dobu 50. a 60. let neobvyklými dramaturgickými úpravami libreta i hudby. $\mathrm{Z}$ těchto důvodů může být Felsensteinovo hudební divadlo dodnes vnímáno jako progresivní, což potvrzují i režiséři jako Joachim Herz, Götz Friedrich, Harry Kupfer či Ruth Berghausová. Všichni jmenovaní se u něho učili operně režijnímu řemeslu a jakkoli rozvíjeli postupy „učitele“ později jiným směrem, zůstal pro ně jedním z iniciátorů oné tendence, již označujeme jako režijní opera. ${ }^{16}$ Ve srovnání $\mathrm{s}$ jejím prudkým rozvojem $\mathrm{v}$ německém prostředí od 70 . let nám bude výtvarný styl Felsensteinových inscenací připadat možná jako vyžilý, málo imaginativní a ve více

15 „Tamino zeigt 1967 ein im Jahre 1967 wahres Verhalten, und das ist - wir können sagen: leider, wir können aber auch sagen: Gott sei Dank - nicht die Wahrheit, nicht die Realität von 1791. Jene Realität kann nicht mehr realisiert werden. So ist das - und nicht um einen Vorwurf auszugleichen, sei hinzugefügt: das überaus geschätzte - realistische Musiktheater eine merkwürdige Form eines Anachronismus, und seine Nomenklatur erweist sich eigentlich als ein termonologisches Zwittergebilde: Es beruft sich auf das Phänomen der Realität, allein diese Realität ist nicht real." Srov. HERBORT, Heinz Josef. Wie „real“ ist das realistische Musiktheater? In Jahrbuch der Komischen Oper Berlin 1966/67. Henschel, Berlin 1967, s. 193-194.

16 Srov. HINTZE, Werner, Clemens RISI a Robert SOLLICH (Hrsg.). Realistisches Musiktheater. Walter Felsenstein: Geschichte, Erben, Gegenpositionen. Theater der Zeit (Recherchen 51), Berlin 2008, zj. příspěvky Joachima Herze, Gerda Rienäckera či Bettiny Brandl-Risi. 
jeho jevištních ztvárněních pravděpodobně i „stejný“. Podobně se bude jevit ve srovnání s dobovým výtvarným abstrakcionismem Wielanda Wagnera v sousedním západním Německu. V hereckém ztvárnění, které tvoří stěžejní bod Felsensteinova „realismu“, budeme postrádat škálu přístupů, jež zastřešujeme nepřesným výrazem „stylizované herectvi“ a s jejichž pomocí mnozí režiséři ještě více „zdivadelňuji““ operní žánr. Na druhé straně nelze opominout ani opačné tendence v soudobém operním divadle, snahy eliminovat „nepravděpodobnost“ opery jako takové a přiblížit ji co nejvíce běžné realitě. Nedávná inscenace Janáčkovy opery $Z$ mrtvého domu v interpretaci jednoho z nejradikálnějších operních režisérů současnosti Calixta Bieita ${ }^{17}$ byla vzorovou ukázkou stylu, který si nejspíše činí ambice působit z hlediska stylu drsným naturalismem. Je však zjevné, že s Felsensteinovým operním stylem, jenž se Joachim Herz nerozpakoval označit jako realismus „poetický“ či „magický“, ${ }^{18}$ má takové pojetí málo co společného.

Když Jarmila Brožovská hodnotila v časopisu Divadlo provedení Straussovy Mlčenlivé ženy a Weberova Čarostřelce v rámci prezentace berlínské Komické opery v Praze roku 1956, zmínila se o dvou předchozích inscenacích Waltera Felsensteina, jež prý v českých operních kruzích vyvolaly značné diskuse - o inscenaci Prodané nevěsty (1950) a Kouzelné flétny (1954). Jakkoli nám nejsou známa jména těch, kteř́i v letech 1950-1956 měli možnost navštívit představení v Komické opeře a přesvědčit se o výjimečnosti jejího intendanta, témata k vzrušeným debatám lze snadno předpokládat. Inscenace Kouzelné flétny představovala jeden z milníků Felsensteinovy tvorby. Šlo o první pokus interpretovat Mozartovo dílo v duchu aktuálně zaměřeného politického divadla. ${ }^{19} \mathrm{U}$ Prodané nevěsty na sebe režisér strhl pozornost už jen tím, že zvolil nejoblíbenější českou národní zpěvohru. Sedmapadesát let po premiéře v němčině uvedl Felsenstein Smetanovu operu ve zbrusu novém překladu. Na rozdíl od volného překladu Maxe Kalbecka, který byl do té doby využíván v německých inscenacích, ${ }^{20}$ vsadil na doslovný převod libreta a ten podrobil vlastní dramaturgické úpravě, jíž předcházela - jako u všech jeho inscenací - detailní analýza dramatických situací a jednání postav. Snahou bylo podtrhnout vážné podtóny komické

17 Premiéra se uskutečnila 12. 3. 2016 ve Státním divadle v Norimberku, domácí publikum se s inscenací mohlo seznámit v rámci mezinárodního festivalu Janáček Brno 2016. Španělský režisér Calixto Bieito (*1963) má na svém kontě několik skandálních inscenací a patří k nejdiskutovanějším divadelním režisérům současnosti. V jeho inscenacích „teče krev“ a močí se přímo před zraky diváků nebo se v nich s oblibou provozuje masturbace či orální sex (takto si kupř. krátí čas ve vězení postavy zmíněné Janáčkovy opery). Jedna část odborných kritiků Bieitův nonkonformní postoj k opeře schvaluje, mnozí však poukazují na jeho často povrchní přístup k inscenovanému dílu a oblíbené jevištní postupy vnímají jako projev marketingové strategie, doprovázené vysokou publicitou jeho inscenací.

18 Srov. HERZ, Joachim: „Einer von den kleinen Felsensteinen...“. Vom Erben, vom Weiterreichen und vom Vergessen. In HINTZE, RISI a SOLLICH (Hrsg.), op. cit., s. 50.

19 Kehrmann nahlíží Felsensteinovu Kouzelnou flétnu ve světle největší události doby, během níž se rodila koncepce inscenace, totiž úmrtí J. V. Stalina. Srov. kap. 6. 3 „Projektionen eines Idealstaates: Sarastro und Stalin“ in KEHRMANN, op. cit., s. 1025-1040.

20 Příklady Kalbeckova nepřesného a místy zavádějícího překladu uvádí ve své eseji „Zur Interpretation der 'Verkauften Braut'“ Carl Riha. V důsledku tohoto překladu byla podle Rihy Smetanova opera v německém prostředí vnímána jako zábavný kus, srovnatelný s vídeňskou operetní klasikou. Srov. RIHA, Carl. Zur Interpretation der „Verkauften Braut“. In Jahrbuch der Komischen Oper Berlin 1966/67. Henschel, Berlin 1967, zj. s. 207-209. 


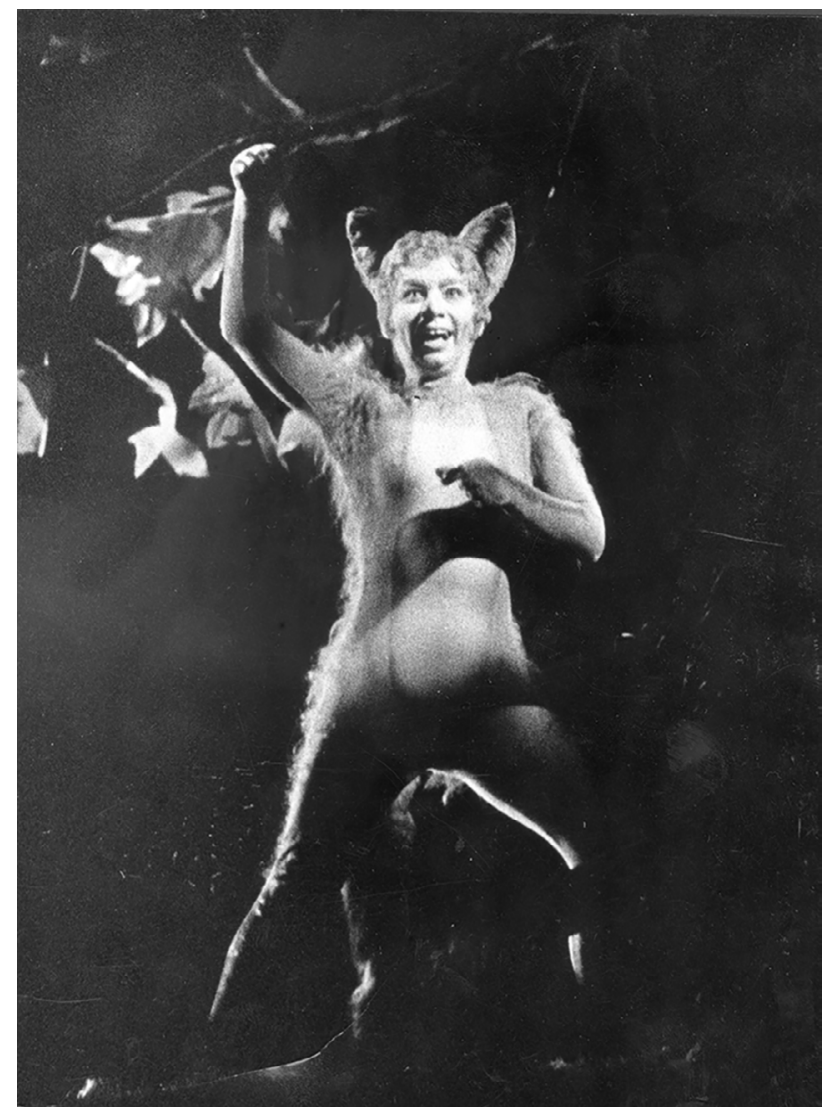

Obr. 2 Leoš Janáček: Liška Bystrouška (Das schlaue Füchslein), Komická opera v Berlíně, 1956. Irmgard Arnold v titulní roli.

Zdroj: Akademie der Künste, Berlin. Walter-Felsenstein-Archiv, sign. 2329.

Foto: Jürgen Simon.

opery. Ty se projevily rovněž ve výkladu postav, tradičně vnímaných jako komických. Tak u Vaška podtrhl jeho touhu po ženském obdivu a uznání, které po selhání s Mařenkou hledá u cirkusového děvčete - Kecala představil jako obět vlastní nenasytnosti a bezmezného přesvědčení, že má všechno pod kontrolou a řídí osudy ostatních lidí. Jako závažné narušení inscenační tradice Smetanovy opery bylo vnímáno ztvárnění úvodního sborového výstupu, který Felsenstein situoval na pole. Lid, oděný do pracovních úborů, zpíval namísto známého „Proč bychom se netěšili, když nám Pánbuh zdravi dá? [...]“ upravený text „Radostně si zazpívejme, když nám práce sílu dává [...]“. Ve skutečnosti to byl jeden z několika mála veršů, v nichž se Felsenstein odchýlil od originálního textu, na jehož přesný překlad do němčiny úzkostlivě dbal. ${ }^{21}$

21 Více k Felsensteinově interpretaci Prodané nevěsty a kritickým ohlasům viz tamtéž. 
Bezprostřední kontakt s výsledky inscenační práce Waltera Felsensteina zprostředkovalo českým divákům zmíněné hostování Komické opery v Praze v roce 1956. Odehrálo se v rámci festivalu Pražské jaro a po zájezdu do Budapešti představovalo teprve druhé zahraniční hostování berlínské scény. Inscenaci oper Mlčenlivá žena a Čarostřelec soubor v Praze uvedl v týdnu od 19. do 25. května 1956. Felsensteinovým původním přáním bylo dovézt Kouzelnou flétnu, ale z technických a časových důvodů plán nakonec padl. ${ }^{22} \mathrm{Je}$ to škoda s ohledem na inscenaci Národního divadla, kterou nedlouho poté (1957) vytvořil dnes legendární režisér Bohumil Hrdlička; ve světle Felsensteinovy netradiční interpretace mohla jeho „skandální“ inscenace doznat citlivějšího posouzení. V této souvislosti je vhodné uvést, že v době pobytu Komické opery v Praze se na jevišti berlínské scény výměnou prezentoval operní soubor Národního divadla s inscenacemi Krútñavy, Rusalky a Dalibora - režisérem prvních dvou byl právě Hrdlička, který následujícího roku v souvislosti s událostmi kolem inscenace Mozartovy opery emigroval do západního Německa. Stal se vyhledávaným operním režisérem a velkým propagátorem Janáčka v zahraničí.

Nejpodrobněji se k pražským představením Komické opery vyjádřila Jarmila Brožovská v recenzi pro časopis Divadlo. ${ }^{23}$ Zatímco představení Mlčenlivé ženy vyzdvihla pro vyrovnanost všech uměleckých složek a označila je za skutečný divadelní zážitek, v Čarostřelci prý Felsenstein nedokázal stylově sjednotit jevištní ztvárnění příběhu. S tajuplnými, fantastickými scénami příliš nesouznělo „naturalisticke“ herectví. ${ }^{24}$ Nebylo ale "přeháněni" Kašparovy „chlapské drsnosti“, „nevázanosti“ „se šilenstvím hraničícího fanatismu“, jak Brožovská líčí, spíše výrazem režisérova tíhnutí k expresivnímu výrazu? Svědčila by pro to poznámka Josefa Kotka, že detailně propracovanými výkony zpěváci, kteř́i prý zvládali party s mimickou a pohybovou přesvědčivostí činoherců, dokázali sami navodit často až „expresionistickou atmosféru hrůzy, v niž se bezmocně zmítá duše ubohých pozemštanư. "25

V archivu Akademie der Künste v Berlíně máme doklad o tom, že Národní divadlo velmi stálo o Felsensteinovo režijní působení a v sezoně 1960/61 opakovaně vzneslo nabídku k pohostinské režii Hoffmannových povidek nebo jiné „německé“ [!] opery. ${ }^{26}$ Felsenstein, jakkoli přímo neodmítl, zdůrazňoval ve svých odpovědích pracovní vytíženost. Jeho poslední nám známý dopis v této záležitosti ze 4. září 1960 nabízí osobní setkání, v jehož rámci by byly projednány všechny náležitosti a podmínky eventuální spolupráce. Zda-li k němu došlo, na základě dochovaných dokumentů ovšem nelze potvrdit.

Jen o pár dnů později od prvního hostování berlínské scény v Praze, 30. května, uvedl Felsenstein v Komické opeře inscenaci Příhod lišky Bystroušky s budoucí pěveckou hvězdou ansámblu Rudolfem Asmusem v roli Revírníka. Domácí publikum se s tehdy ojedinělou interpretací Janáčkovy opery mohlo seznámit až roku 1962; ve Smetanově divadle byl opět v rámci Pražského jara uveden ještě Verdiho Othello. ${ }^{27} \mathrm{~V}$ plánu bylo dále uvedení

22 Srov. dt. W. Felsenstein v Praze. Večerni Praha, 14. 5. 1956.

23 Srov. BROŽOVSKÁ, Jarmila. Felsensteinovy inscenace v Praze. Divadlo, roč. 7 (1956), č. 7, s. $597-601$.

24 Tamtéž, s. 600.

25 KOTEK, Josef. Berlínská komická opera se představila v Praze. Mladá fronta, 24. 5. 1956.

26 Vzájemná korespondence z období od listopadu 1959 do září 1960 obsahuje 8 dopisů, kromě operního šéfa Jana Seidla nabídku Národního divadla tlumočily Hudební a divadelní agentura a Deutsche Konzert.

27 Představení opery Leoše Janáčka se konalo 27. a 29. května, představení Othella 24., 26. a 28. května. 
Brittenova Snu noci svatojánské, které mělo pražské hostování Komické opery uzavírat. $\mathrm{Z}$ neznámých důvodů však $\mathrm{k}$ jeho realizaci nedošlo. $\mathrm{O}$ důkladných přípravách na zájezd a vystoupení ve Smetanově divadle svědčí dochované protokoly z porad vedení Pražského jara, Národního divadla, ministerského divadelního odboru a dalších institucí se zástupci Komické opery v čele s Walterem Felsensteinem. V archivu Národního divadla je uložena zpráva o návštěvě delegace v Praze ve dnech 10.-13. ledna $1962 .{ }^{28} \mathrm{~V}$ archivu Akademie der Künste v Berlíně pak jsou deponovány zápisy o jednání s českou stranou v Berlíně, jež proběhlo nedlouho poté, ve dnech 27. a 29. ledna. ${ }^{29}$ Ze všech dokumentů vyplývají vysoké nároky berlínské scény na zajištění pražského vystoupení. Na představení Othella Národní divadlo participovalo 11 instrumentalisty ( 8 trumpetistů a 3 pozounisté) a 20 sborovými zpěváky. V dílnách Národního divadla bylo dále pořízeno speciální proscénium za účelem zvětšení jeviště pro davové výstupy: tak jako na jevišti Komické opery, rovněž v pražském představení se na tomto proscéniu odehrál závěrečný Otellův výstup, aby v divákově bezprostřední blízkosti získal na zvláštní naléhavosti.

Při př́ležitosti hostování Komické opery v Praze udělila Karlova univerzita Walteru Felsensteinovi čestný doktorát. V Kulturním a informačním středisku NDR pak mohli návštěvníci Pražského jara a příznivci Komické opery zhlédnout výstavu, rekapitulující dosavadní činnost divadla. Walter Felsenstein se stal v českých operních kruzích fenoménem. Připomínán byl jeho vstřícný vztah k našim interpretům. Na tomto místě se sluší zmínit české zpěváky, které do Komické opery angažoval počínaje rokem 1956: kromě nejznámějšího z nich, Rudolfa Asmuse, ${ }^{30}$ Jarmilu Kšírovou, ${ }^{31}$ Vladimíra Bauera, ${ }^{32}$ Jaroslava Kachela ${ }^{33}$ a v sedmdesátých letech Janu Smítkovou ${ }^{34}$ a Klemense Słowioczka. ${ }^{35}$ Pěvců, kteří s Felsensteinem jednali o možném angažmá na základě předzpívání, bylo

28 Srov. sign. AND - Z 387.

29 Srov. Walter-Felsenstein-Archiv, sign. 3086.

30 Rudolf Asmus (1921-2000) byl Felsensteinem angažován v roce 1956 a v Komické opeře setrval do konce života (od roku 1988 byl jejím čestným členem). Vyjma Othella a Carmen (1972) hrál ve všech Felsensteinových inscenacích.

31 Jarmila Kšírová (1910-1983) byla členkou ansámblu Komické opery v letech 1948-1967. Jako svou první roli zde ztvárnila Carmen (1949), v dalších inscenacích režírovaných Felsensteinem se ujala role Metelly v Pařižském životě (1951) a Jenty v muzikálu Šumař na střě̌e (1971).

32 Vladimír Bauer (1925-1991) byl angažován roku 1959 a členem Komické opery byl až do své smrti. Hrál významné role ve Felsensteinových inscenacích Othello (Jago), La traviata (Germont), Hoffmannovy povídky (Spalanzani) a Rytír Modrovous (Popolani - v alternaci s Rudolfem Asmusem).

33 Jaroslav Kachel (1932-2007) působil v Komické opeře jako člen ansámblu v letech 1962-1971. První rolí, kterou ztvárnil, byl Othello (v alternaci s Hannsem Nockerem, se kterým alternoval také v roli Modrovouse a Lazara Wolfa z muzikálu Šumař na střeše).

34 Jana Smítková (1942) přijala angažmá roku 1973 na základě účinkování v titulní roli Herzovy inscenace Káti Kabanové. Jako Micaela (Carmen) a Örzse (Háry János) účinkovala v inscenacích Felsensteina. V Komické opeře působila do roku 1993.

35 Klemens Słowioczek (1945) získal angažmá roku 1975. Při předzpívání v pražském Národním divadle si jej pro roli Figara vybral sám Felsenstein, který v něm prý viděl druhého Asmuse (proti původnímu plánu však premiéru nezpíval a v inscenaci vystupoval až po Felsensteinově smrti). Své působení v Komické opeře ukončil roku 2005. 
celkem hodně. Z nám známých písemných dokumentů ${ }^{36}$ vyplývá, že předzpívání absolvovali Antonia Denygrová, Vladimír Krejčík, ${ }^{37}$ Jaroslav Souček ${ }^{38}$ Naděžda Kniplová, Jitka Kovaříková, Zdeněk Kroupa, Marie Kremerová, Věra Soukupová, ${ }^{39}$ Daniela Šounová, Magda Špaková a Jarmila Rudolfová. O audienci se dožadovala dále Věra Krilová a Marie Steinerová, ${ }^{40}$ přičemž není jisté, zda k předzpívání došlo. V některé z rolí repertoáru hostovali Viktor Kočí, Oldřich Spisar, zmíněná Jarmila Rudolfová a Karel Berman (všichni v 60. letech) nebo Libuše Márová (70. léta). Na uměleckých úspěších Komické opery se v éře Waltera Felsensteina podílely rovněž dvě významné dirigentské osobnosti - Václav Neumann (působil zde v letech 1955-1959) a Zdeněk Košler (1965-1968).

Soustavnější domácí reflexi Felsensteinovy koncepce hudebního divadla a jeho inscenačních děl můžeme pozorovat od počátku 60. let. Je zřejmé, že největší počet článků vyšel v roce 1962 v souvislosti s diskusemi o inscenaci Janáčkovy opery. V recenzích byla zdůrazňována vysoká profesionalita režisérovy práce a výkonů celého souboru, jež byla dávána za příklad domácím operním divadlům. Fascinaci přísným vedením souboru a disciplínou zpěváků vyjádřili Eva Herrmannová s Vladimírem Léblem, kteří se účastnili zkoušek Lišky Bystroušky u příležitosti pražského uvedení:

„Felsensteinovy zkoušky jsou koncertem tvůrčí fantazie, pevné logiky, pracovní soustředěnosti a jedinečné kolektivní discipliny. Improvizace a náhodnost jsou v Komické opeře vyloučeny, tady se promýšlí a pevně fixuje každý pohyb, každé gesto, každý výrazový odstín. Od operního pěvce se vyžaduje akrobatické zvládnutí role: všechno fyzické jednání musí přejít do krve, musí se při představení vybavovat se stejnou samozrejmostí, s jakou artista provádí životu nebezpečný cvik. Představitel učitele v Lišce má svůj pád nacvičen a vypočítán na půlmilimetr př̀esně; obtíže pěveckého řemesla mizí zásluhou nekonečného počtu zkoušek, všechny reakce jsou automatické, pěvec se může dokonale soustředit na vrcholný tvůrčí akt proživání.“41

36 V archivu AK (Walter-Felsenstein-Archiv, sign. 3697) se nachází rozměrná kartotéka záznamů o průběhu předzpívání pěvců z různých zemí Evropy včetně Československa před komisí, složenou z činitelů Komické opery v čele s Felsensteinem. Každý záznam obsahoval stručné zhodnocení hlasových a výrazových dispozic zpěváka.

37 Tenorista Vladimír Krejč́́k dostal od Felsensteina velkorysou nabídku zazpívat si každý rok v Komické opeře jednu roli, z čehož však pro adeptův nezájem sešlo. Srov. Walter-Felsenstein-Archiv, sign. 3697, Vladimír Krejčík, Praha 20. 5. 1962.

38 Barytonista Jaroslav Souček Felsensteina svým projevem v rolích Rigoletta a Kníže Igora při předzpívání doslova nadchl. Jeho hlasová technika i pěvecký výraz zanechaly na všechny členy komise „fascinující dojem“, okamžitou nabídku angažmá ale Souček nepřijal a místo toho nastoupil do brněnské opery. Srov. Walter-Felsenstein-Archiv, sign. 3697, Jaroslav Souček, Praha 20. 5. 1962.

39 O tehdejší sólistce opery Národního divadla Věře Soukupové, která předzpívala v rolích Favoritky a Aidy, se Felsenstein vyjádřil pochvalně slovy, že altistku s tak vyrovnanými tóny ještě neslyšel. Do poznámek si napsal, že vyniká „muzikalitou“, „vitalitou“ a „výrazovou škálou“. Ocenil rovněž její herecké schopnosti. Byla by prý vynikající v roli Azuceny. Srov. Walter-Felsenstein-Archiv, sign. 3697, Věra Soukupová, Praha 20. 5. 1962.

40 Srov. korespondenci v archivu AK (Walter-Felsenstein-Archiv, sign. 4186).

41 Srov. HERRMANNOVÁ, Eva a Vladimír LÉBL. Janáček, Felsenstein a Komická opera. Literárni noviny, roč. XI (1962), č. 23, s. 1. 
Někteří kritikové si povšimli, že po pěvecko-technické stránce nebyly výkony interpretů Komické opery zcela bezchybné, což jen potvrzuje známý fakt, že v inscenacích, které Felsenstein režíroval, bylo na prvním místě herecké vyjádření dramatického děje. Pokud bylo Felsensteinovi opravdu něco vytýkáno, pak většinou popisnost výpravy. Hudební kritikové také poukazovali na volné zacházení s hudební partiturou; diskutovalo se kupříkladu o tom, zdali je možné, aby režisér měnil předepsanou melodii a nahrazoval ji parlandy, neintonovanými výkřiky a jinými projevy na pomezí zpěvu a mluvy. ${ }^{42}$ Jednu z typických výhrad shrnul Jiří Bajer v zamyšlení Achillova pata Komické opery? Položil otázku, není-li schopnost režiséra vypracovat jevištní tvar do nejmenšího detailu a doslovit významy operního díla do definitivní „pravdy“ vlastně limitujícím faktorem uměleckého zážitku, nebot divákovi není ponechán dostatečný prostor k samostatnému domýšlení významů . ${ }^{43}$ A někteří recenzenti rozvíjeli své výhrady dál; objevily se i pochybnosti, jestli slavný německý režisér vlastně divadlem neutiskuje hudbu. Jaromír Paclt v recenzi Felsensteinův Othello, vzniklé na základě jím zhlédnutého představení Verdiho opery přímo v Berlíně, konstatoval, že Felsenstein se nahromaděním jevištně výrazových prostředků v zájmu „vševyčerpávajiciho vyjádřeni zvukové partitury“ dostal až na hranici možného. Jako názorný příklad uváděl legendární scénu bouře: divák nejenže nedokáže smysly kompletně pojmout scénickou přesycenost detaily, ale výsledkem prý je doslova absence vnímání Verdiho hudby. ${ }^{44}$ Jiří Bajer k tomu ve výše citovaném článku dodal, že dualita intenzivního hudebního i jevištního vyjádření přináší v konečném důsledku vlastně opačný efekt, než jakého chtěl Felsenstein dosáhnout, totiž že jedna složka potlačí tu druhou.

Neuralgickým bodem domácí diskuse nad Felsensteinovým jevištním stylem se pochopitelně stala inscenace Janáčkovy opery, v níž režisér vyzdvihl motiv lásky s důrazem na erotické momenty v jednání zvířecích i lidských postav. Těžiště polemik představovala dramaturgická úprava díla, která byla nesena snahou vnést do př́iběhu větší dramatičnost, učinit věrohodnější psychologii, vztahy a motivy jednání postav. Felsenstein vyšel z překladu Maxe Broda, který se od originálního libreta znatelně vzdálil. Nejvýraznější změnou bylo akcentování postavy Terynky jako lásky revírníka, rechtora (platonické) i faráře a domyšlení analogie mezi touto ženskou postavou a Bystrouškou. ${ }^{45}$ Felsensteinův zásah do Janáčkovy opery odsoudila naprostá většina českých kritiků, výhrady měli i operní režiséři. Václav Věžník, známý proklamacemi o nezbytně pietním vztahu k partituře, označil Felsensteinovu interpretaci ještě i po letech za neomluvitelné nakládání s originálním

42 Srov. např. BAJER, Jiří. Achillova pata Komické opery? Divadelni noviny, roč. 5 (1962), č. 23, s. 8. Dále srov. VOJTĚCH, Ivan (šifra iv). Dilema operního herectví. Felsenstein 1962. Divadlo, roč. 13 (1962), č. 7, s. 52-53. A dále HERRMANNOVÁ a LÉBL, op. cit.

43 Srov. BAJER, op. cit. V tomto smyslu se vyjádřili také Eva Herrmannová s Vladimírem Léblem, když vznesli námitky proti Felsensteinovu rozhodnutí pozměnit janáčkovskou mnohovýznamovou zkratku. Vadilo jim, že Felsenstein zkrotil jistou naivitu v příběhu o lišce Bystroušce, vybízející však k divákově představivosti, ve jménu př́ísné dějové logiky. Srov. HERRMANNOVÁ a LÉBL, op. cit., s. 1.

44 Srov. PACLT, Jaromír. Felsensteinův Othello. Divadelni noviny, roč. 3 (1959/60), č. 4, s. 8.

45 Paralelu mezi Terynkou a Bystrouškou vyjádřil Felsenstein v prvním jednání, ve scéně Bystrouščina snu, který měl podobu milostného setkání revírníka s Terynkou. A tudíž v momentě, kdy Bystrouška v závěru opery umře, promítne se v divákově vědomí motiv smrti zvířecí hrdinky do osudu revírníkovy lásky k Terynce. 
dílem. ${ }^{46}$ Také kupř. Ladislav Štros, který měl k Felsensteinovi obecně značné výhrady, ji ostře odmítl jako důsledek „chtěné dramatičnosti“. Z jeho pohledu mělo jít o „násilnou dramaturgickou chirurgii, která neodpovídala smyslu dila“. ${ }^{47}$ Ve jménu větší pravděpodobnosti se Felsenstein rovněž odhodlal k přeobsazení rolí Lišáka, Lapáka a Kohouta, ze kterých udělal role „mužské“. (Tímto řešením se inspiroval ve své pozdější inscenaci z roku 1965 Miloš Wasserbauer, který postavu lišáka Zlatohřbítka rovněž obsadil tenorem.) Domácí kritiku pak dráždila i popisně realistická výprava, což mělo zřejmě souvislost s brněnskou premiérou z roku 1924 v kubistických kostýmech a scénografii Eduarda Miléna, kterou prý sám Leoš Janáček přijal s neskrývaným nadšením. K prvkům naturalismu ve výpravě k berlínské inscenaci se vyjádřil odmítavě kupř. režisér Václav Kašlík, který Janáčkovu operu inscenoval vícekrát (v Německu dokonce třikrát). ${ }^{48}$

Na zpo̊sob výtvarného ztvárnění Janáčkovy opery v památné premiéře z dvacátých let v režii Oty Zítka navázal v roce 1965 tvưrčí tandem Miloš Wasserbauer a František Tröster. Jejich inscenaci lze zároveň považovat za nejvýznamnější režijní příspěvek do diskuse s opusem Waltera Felsensteina. Ani Wasserbauer nesouhlasil s výše zmíněnou dramaturgickou úpravou ve jménu větší dramatičnosti opery (jakkoli on sám obecně proti razantnímu zásahu do skladatelského díla, pokud to režijní koncepce vyžadovala, nic nenamítal). Jestli mu však na Felsensteinovu výkladu Janáčkova díla něco opravdu hodně vadilo, pak to byl iluzivní výtvarný rámec v provedení scénografa Rudolfa Heinricha. Ve svém vlastním pojetí se nezříkal v podstatě realistického řešení výstupů ze světa lidí, o to více však podtrhl poetický rozměr a snovou atmosféru lesa, naznačeného za pomoci soustavy abstraktních tvarů. Ve spolupráci s výtvarníkem využil bohatých kinetických možností brněnského, tzv. nového Janáčkova divadla, jež touto inscenací vstoupilo do první sezony existence. Akce živých herců na scéně se důmyslně prolínala s hrou projekcí a dalších světelných efektů. ${ }^{49}$ Scénicky tedy Wasserbauer pojednal inscenaci mnohem odvážněji než jeho německý kolega a ani on se nevyhnul hlubším úpravám, z hlediska dosavadní janáčkovské inscenační praxe málo obvyklým. Oproti Felsensteinovi se ale snažil, aby zbavil Janáčkovu operu všeho nadbytečného. Jeho nejvážnější zásah spočíval v redukci zvířecích postav, z nichž ponechal pouze ty, jež jsou důležité pro dramatický děj. Za zvláště diskutabilní považovali recenzenti eliminaci baletu (výstupy vážky a mušek, svatební rej).

Pátráme-li v českém operním divadle 60. let po režisérovi, který nejvíce reagoval na Felsensteinův koncept hudebního divadla, pak to byl dozajista právě Miloš Wasserbauer. Vztah Wasserbauera k práci Waltera Felsensteina lze charakterizovat podobností tvưrčích

46 Rozhovor Heleny SPURNÉ s Václavem Vě̌̌níkem z ř́ijna 2016 (audionahrávka v soukromém archivu HS).

47 Srov. ŠTROS, Ladislav. Jak jsem v Praze inscenoval Janáčka. Opera. Informační zdroj SOP (1995/96), č. 3 (26), s. 23. Štros svou vlastní inscenaci Př̌hod lišky Bystroušky, která vznikla tři roky po pražském uvedení inscenace Felsensteina, formuloval výslovně jako polemiku s koncepcí tohoto operního režiséra.

48 Ve své autobiografii se zmínil, že když naopak Felsenstein osobně zhlédl jeho inscenaci Př́hod lišky Bystroušky v Národním divadle (1954), prohlásil, že takové pojetí odporuje „správnému“ inscenačnímu př́stupu k Janáčkově opeře. Srov. KAŠLÍK, Václav. Jak jsem dělal operu. Panton, Praha 1987, s. 57.

49 Popisem výtvarného a celkově inscenačního řešení opery v režii Miloše Wasserbuera se zabývala ve své diplomové práci Dana Toncrová. Srov. TONCROVÁ, Dana. Miloš Wasserbauer a jeho hledání realistické scénické interpretace v opeře (Tuorba Miloše Wasserbauera ve Státním divadle Brno v letech 1958-1970). Diplomová práce, Filozofická fakulta MU, Brno 2000, s. 62-73. 
názorů a samotných východisek tvorby. Není možné konstatovat, že by se Wasserbauer ve svých inscenacích přímo a zásadně Felsensteinovou tvorbou inspiroval. Spíše na ni reagoval, a to v mnohém právě přes dobový kontext, v němž Felsensteinova tvorba rezonovala. Rozhodně však nešlo o bezmyšlenkovité následování Felsensteinových režijních postupů. Divadelní historička Eugenie Dufková, která byla s Wasserbauerem v blízkém pracovním kontaktu, dokonce konstatovala jeho velmi vyhraněný postoj k Felsensteinově práci, $\mathrm{k}$ níž měl i řadu výhrad, jakkoli je vyjadřoval víceméně v kuloárech..$^{50} \mathrm{Na}$ druhé straně nelze přehlížet projevy Wasserbauerovy ctižádosti navázat s Felsensteinem důvěrnější kontakt. Víme, že už roku 1958 se s ním u přiležitosti mezinárodního kongresu konaného v Brně v rámci Janáčkova festivalu setkal osobně. Felsenstein krátce hovořil o svém poměru $\mathrm{k}$ Janáčkovi a o originálním přínosu tohoto skladatele hudbě 20. století, přičemž Wasserbauer na jeho myšlenky ve vlastním příspěvku pohotově a souhlasně zareagoval. ${ }^{51}$ Felsenstein se naopak pochvalně vyjádřil o inscenaci $Z$ mrtvého domu, kterou Wasserbauer v rámci zmíněného festivalu představil.$^{52}$ Dopis z počátku června roku 1961 u př́ležitosti Felsensteinova životního jubilea nás už nenechá na pochybách, že Wasserbauerovi at̉ z osobních nebo čistě profesně kariérních důvodů velmi záleželo na tom, aby slavný německý režisér věděl o jeho náklonnosti. Zdůrazňuje obohacující vliv Felsensteinovy umělecké práce na vlastní tvorbu, vyjadřuje berlínskému kolegovi hlubokou úctu a obdiv k tomu, co dokázal, a ujištuje jej, že „hlavním principưm“ jeho režijní práce ,zưstane vždycky věrný ${ }^{\prime 53}$ Wasserbauer Felsensteinovu tvorbu sledoval jako málokterý český režisér, jak dokládá ještě i pozdější jejich vzájemná korespondence. Wasserbauer stavěl vždy před režiséra jako hlavní jeho úkol přiblí̌it operní dílo modernímu diváku, přičemž rád akcentoval společensko-politickou rovinu příběhu a hledal způsoby jejího jevištního vyjádření ( $\mathrm{v}$ Brně v 60 . letech naplňovala opera program sociálně angažované tvorby souběžně $\mathrm{s}$ činohrou). Nikdy nepřestal směřovat $\mathrm{k}$ realistickému divadlu a Felsenstein mu v dobovém evropském kontextu logicky představoval orientační bod, od něhož odvíjel své představy o podobě operní inscenace. Je třeba zdůraznit, že žádný jiný český operní režisér té doby se operou nezaobíral tak do hloubky a s takovým zaujetím pro teoretické otázky jako Wasserbauer. Nevíme, jakými cestami se k Felsensteinovu teoretickému dílu dostal, ale jeho úvahy o opeře a otázkách operní dramaturgie a inscenace svědčí o tom, že myšlenkový odkaz německého režiséra studoval a nechal se jím ve svých vlastních vyjádřeních inspirovat. Hlásil se už k Felsensteinově výchozí tezi, že

50 Srov. rozhovor Š. HAVLÍČKOVÉ KYSOVÉ ze dne 16. 3. 2016 (audionahrávka v soukromém archivu ŠHK).

51 Po letech vyšel v Pantonu obsáhlý sborník z tohoto kongresu, který obsahuje oba př́spěvky. Srov. Leoš Janáček a soudobá hudba. Sborník z Mezinárodního hudebně vědeckého kongresu v Brně 1958. Panton, Praha 1963 , s. $88-89$ a $381-386$.

52 Srov. FELSENSTEIN, Walter. K interpretaci Janáčkových oper. Hudebni rozhledy, roč. 11 (1958), č. 22, s. 925. Podrobně k Wasserbauerově inscenaci opery $Z$ mrtvého domu i k Felsensteinově reakci na ni viz HAVLÍC̆KOVÁ KYSOVÁ, Šárka. Teoretické dílo Miloše Wasserbauera v kontextu dobového myšlení o operní inscenační tvorbě. In Theatralia, roč. 20 (2017), č. 2, s. 87-91.

53 „Ich versichere Ihnen [!], sehr geehrter Herr Intendant, meiner tiefen Hochachtung und bitte Sie, an meiner Bewunderung Ihrer Kunst, deren Hauptprinzipien ich immer treu bleiben werde, nie zu zweifeln. "Srov. dopis Miloše Wasserbauera dat. 2. 6. 1961, archiv AK v Berlíně, Walter Felsenstein, sign. 4780. 
opera nesmí být „kostýmovaným koncertem“, že je třeba usilovat o její „zdivadelněn ^“. ${ }^{4}$ Také Wasserbauer zdůrazňoval, že inscenační záměr se musí podřídit partituře (sám přitom reprezentoval typ režiséra, který v samostatném domýšlení partitury zacházel ve své době nebývale daleko a se skladatelovým záměrem se dostával až do sporu). Stejně tak přijal za svou vlastní Felsensteinovu premisu, že hlavními nositeli hudebně divadelního zážitku musejí být „operni herci“, 55 a považoval v rámci scénické interpretace opery za nejdůležitější, aby režisér spolu se zpěváky dosáhl „vnitřni pravdivosti“ a „přirozenosti“ v jednání postav. ${ }^{56}$ Pojem realismus chápal tak jako Felsenstein v širším slova smyslu - nikoli tedy jako označení stylu, nýbrž ve významu obsahové hodnověrnosti a přesvědčivosti. Současně ale dodával, že scénická interpretace opery působí až tehdy „pravdive““ a „přirozeně“, když režisér dosáhne jednoty jevištního výrazu s výrazovými prostředky dané opery. Jinak řečeno: režisér podle něj musí vycházet z charakteristického slohu inscenovaného díla, který mu určí míru jevištního realismu, resp. stylizace.${ }^{57}$ A právě v tomto bodě vstupoval s Felsensteinem do neskrývané polemiky. ${ }^{58}$ Wasserbauer uváděl např́klad nezbytnost dodržet v inscenacích starších oper dualismus recitativu (s jeho dynamičností) a árie, vyznačující se naopak statičností. (V inscenaci Myslivečkova Tamerlána z roku 1967 nechal árie zpívat na malém stupínku nejblíže publiku a doprovodit je sošnými gesty interpretů,

54 „Vysoce vyzvedávám zásluhu Waltera Felsensteina o zdivadelněni opery a v tomto bodě jdu s ním společnou cestou.“ Srov. WASSERBAUER, Miloš. Interpretace opery, jak já ji cítím a jak se o ni pokouším. Rkp. [1], soukromý archiv Aleny Mášové. Cit. dle TONCROVÁ, op. cit., s. 17.

55 „Považuji herce a jeho pravdivé herectvi v opeře za jádro, za samu podstatu operni interpretace." Cit. dle TONCROVÁ, op. cit., s. 17.

56 V Poznámkách pro sólisty inscenace Síly osudu G. Verdiho v Lipsku, které Wasserbauer sepsal roku 1963 u příležitosti svého hostování jako režiséra v lipské Opeře, uváděl, že v „realistických inscenacích“ má být nejdůležitějším prostředkem režiséra jednání herců na scéně: „Ti jsou hlavními nositeli pưsobeni díla na diváka a z míry pravdivosti pocitů a myšlenek, které jsou vyjádřeny jako dramatické ztvárněni díla, z míry věrohodnosti jejich vzájemných vztahů a vztahů $k$ prostředí, ze správného jednání postav, [...] se odvíji síla realistického působeni na publikum. " Strojopis [1], pozůstalost Miloše Wasserbauera v divadelním oddělení Moravského zemského muzea v Brně, nesign.Wasserbauerův text, z nějž citujeme, je jasným dokladem toho, že byl poučeným čtenářem Felsensteinových úvah o hudebním divadle. Zjevně mu záleželo na tom, aby jeho německý kolega inscenaci Síly osudu zhlédl. Svědčí o tom dopis, který slavnému režisérovi 4. 9. 1963 adresoval z Lipska v době zkoušek právě na tuto inscenaci (Felsensteina v něm mj. jiné ujištuje, že se chystá navštívit nějaké jeho představení v berlínské Komické opeře). V pozůstalosti se dochovala i Felsensteinova odpověd' z 11. 9. t. r., zvoucí českého kolegu na premiéru Rytíre Modrovouse.

57 „Odraz životni skutečnosti je v každém uměni jen tehdy pravdivý, je-li vyjádřen uměleckými prostředky. Tyto umělecké prostředky - formu, styl - voli sám tvuirči umělec, hudebni dramatik. Z nich pak nutně musí vycházet forma a styl scénické reprodukce, za něž je odpověden operni režisér. Nejsou-li tyto prostředky v dokonalém souladu a pravdivé závislosti na hudebnich vyjadřovacich prostředcich skladatelových, nemůže scénická interpretace dila působit pravdivě a přirozeně." Srov. WASSERBAUER, Miloš. Princip realistické scénické interpretace v opeře. Divadlo, roč. 8 (1957), č. 3, s. 211.

58 Režisérka Alena Vaňáková, která léta působila jako Wasserbauerova asistentka, se vyjádřila, že Wasserbauer u Felsensteina postrádal různorodost inscenačního přístupu. Vadilo mu, že ve scénickém zpracování nebral ohled na specifičnost kompozičního zpracování a umělecký styl doby, v níž bylo dílo vytvořeno. V jeho pohledu byl Felsensteinův Mozart prý stejný jako Verdi. (Srov. rozhovor Heleny SPURNÉ s Alenou VAŇÁKOVOU ze září 2016, audionahrávka v soukromém archivu HS.) Wasserbauer své výhrady zveřejnil roku 1964 v Hudebnich rozhledech, kde v rozhovoru s Rudolfem Pečmanem uvedl, že na rozdíl od Felsensteina nepoužívá „jednu jedinou ( $t j$. realistickou) formu jevištniho projevu herce $k$ interpretaci oper rüných kompozičnich slohü“. Srov. PEČMAN, Rudolf. O opeře s Milošem Wasserbauerem. Hudebni rozhledy, roč. 17 (1964), s. 186. 
recitativním výstupům, které výrazně rozehrál po pohybové stránce, naopak ponechal celou plochu scény. $)^{59}$ Nejblíže ale měl tento režisér k opeře 20. století, snad proto, že nejvíce souzněla s moderním jevištním výrazem, který svým inscenacím s pomocí soudobých uměleckých i technických prostředků scény dokázal vtisknout. Pokud šlo o herectví, nepřestával Wasserbauer nikdy operovat s představou psychologické charakteristiky ve ztvárnění postavy, jakkoli opět zdůrazňoval, že „sloh skladatelský je [...] určovatelem i formy jevištniho projevu herce [... ] inspiraci $k$ domyšleni, $k$ dotvořeni, $k$ nalezeni, was ungesagt ist, rečeno s Felsensteinem. "60 Jeho inscenace jsou dokladem, že tak jako vesměs všichni čeští operní režiséři šedesátých let, usiloval i on o dosažení psychologicky věrohodné postavy, tu s větší, tu s menší mírou pohybové stylizace.

Co se týče integrování vlivu Stanislavského do vlastní tvůrčí práce, ve srovnání s Felsensteinem se odkazy na Stanislavského systém výchovy herce pravidelně objevují jak v reflexích Wasserbauerovy operně režijní tvorby, tak v jeho vlastních textech. Jde povětšinou spíse o zmínky či pasáže drobného rozsahu, které čtenáři nijak systematicky neozřejmují podstatu této metody a mnohdy ani nejsou př́liš konkrétní, pokud jde o postupy, jež jsou od Stanislavského přejímány. O něco obsáhleji a konkrétněji než recenzenti se o své tvůrčí metodě v souvislosti s postupy Stanislavského vyjadřuje Wasserbauer sám. Činí tak především ve spojitosti s inscenacemi Mladé gardy (1951) a Tarasovy rodiny (1952), zejména když hovoří o pečlivém studiu využívajícím pomocného a historického materiálu při práci na inscenaci atp. Lze souhlasit s názorem Dany Toncrové, která vysvětluje, že Wasserbauer prohlašoval za východisko své práce s hercem postupy Stanislavského „[n]epochybně pod viivem obecných tendenci zkreslených výkladů systému Stanislavského a jejich aplikace na činohru, operu, balet nebo loutkové divadlo“. ${ }^{61}$

Otázkou samožrejmě zůstává, do jaké míry si byl Wasserbauer vědom zkreslenosti obecného povědomí divadelníkủ jeho doby, a tedy i jeho samotného, o systému Stanislavského. Nelze bohužel jednoznačně určit, kde čerpal poznatky o této metodě. V odkazech na Stanislavského a stručných popisech konkrétních postupů, které z jeho systému přebíral, lze Wasserbauerův postoj $\mathrm{k}$ této koncepci tvorby charakterizovat jako vědomě inspirovaný a selektivně přijímaný vliv na vlastní režijní práci. Ostatně Wasserbauer opakovaně vyjadřoval nevůli vůči mechanickému či direktivně důslednému aplikování této (či snad jakékoliv) metody na vlastní práci, bez promýšlení a hledání nových postupů. Není proto zřejmě tak zásadní se ptát, jak dobře byl Wasserbauer seznámen se Stanislavského pojetím herecké tvorby. Důležité je především to, co si pod pojmem „Stanislavského metoda" představoval, tj. co proklamativně považoval za metody své vlastní tvorby a čím z toho se řídil. V kontextu přístupu Stanislavského tvorby pak je třeba pouze identifikovat konkrétní styčné body Wasserbauerovy práce s jeho ruským „vzorem“. Některé aspekty, v nichž se Wasserbauer inspiroval u Stanislavského, identifikovala Dana Toncrová. Předně šlo o onu „pravdivost“ v oblasti zobrazení umělecké skutečnosti, jíž byla charakterizována tehdejší realistická interpretace operního díla na scéně, dále „služba“

59 Blíže o této inscenaci viz ŠALDOVÁ, Lenka. Česká operni režie v šedesátých letech 20. století. Disertační práce, Filozofická fakulta UK, Praha 2005, s. 47. Zde též seznam recenzí k uvedené inscenaci Tamerlán.

60 Srov. WASSERBAUER, op. cit., s. 211.

61 Srov. TONCROVÁ, op. cit., s. 13. 


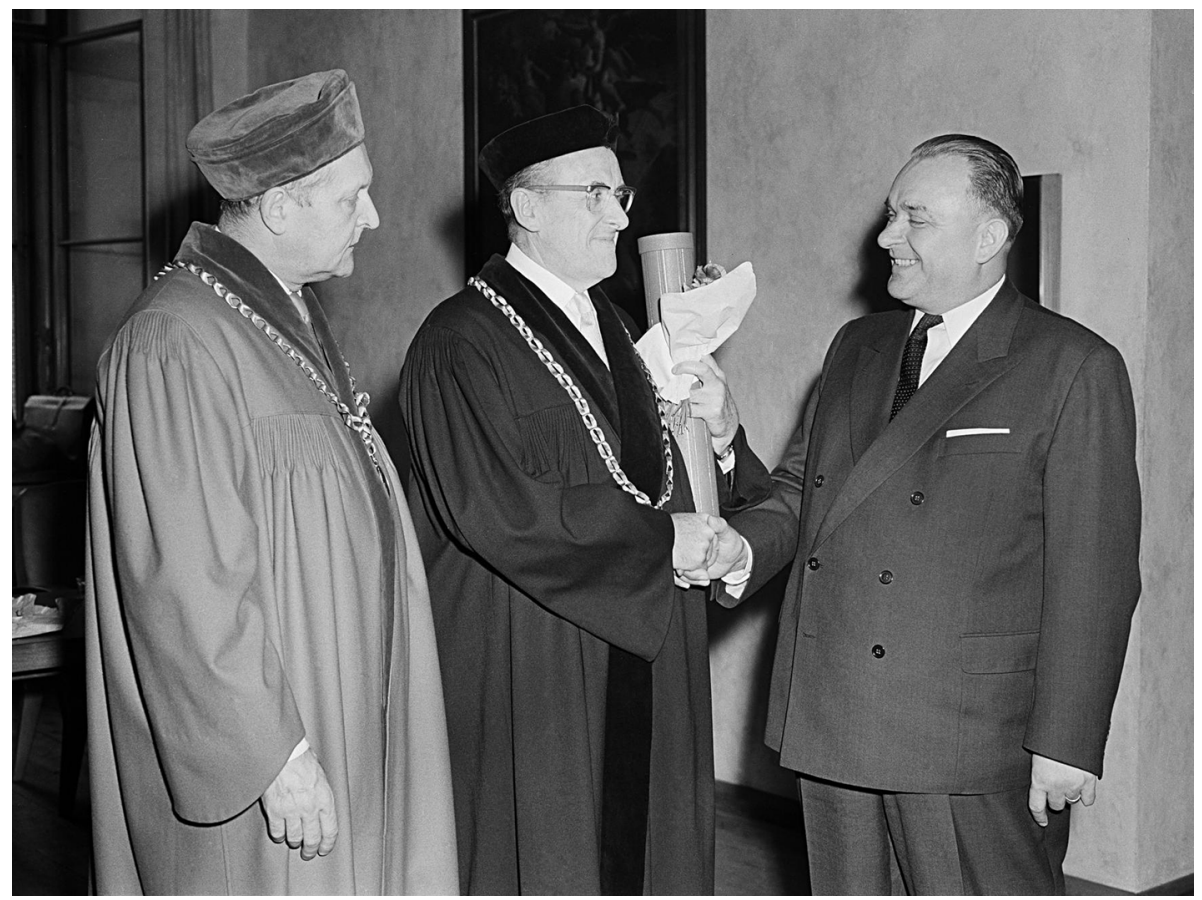

Obr. 3 Zleva: Karel Pravoslav SÁDLO (prorektor AMU), Walter FELSENSTEIN a František KAHUDA (ministr školství a kultury). Snímek pořízený 29. 5.1962 u př́ležitosti udělení čestného doktorátu Univerzity Karlovy W. Felsensteinovi. Zdroj: ČTK. Foto: Jovan Dezort.

režiséra autorovi, hledání a zprostředkování ústřední ideje díla, související s oním „proč“ autor dílo psal, jak Wasserbauer často uvádí, či - jak to formuluje Toncrová - „pojetí herce jako ústředního nositele významových kvalit dila" ${ }^{62} \mathrm{~K}$ těmto postupům samozřejmě patří i pečlivá př́íprava členů inscenačního týmu včetně herců, pojatá jako důkladné studium doprovodného a historického materiálu, a kladení důrazu na kolektivní práci, včetně jejího vzájemně inspirativního a korektivního potenciálu atd.

Jestliže ve Wasserbauerovi - bez ohledu na dílčí rozpory - našel Felsenstein v rámci českého divadla vưči sobě nejchápavějšího režijního kolegu, jistá část domácích tvưrců vnímala jeho myšlení o opeře a inscenační styl v podstatě za překonaný. Navzdory tomu, jaký význam byl Felsensteinově inscenační tvorbě a koncepci hudebního divadla z hlediska vývoje soudobého operního divadla přisuzován, česká opera čerpala od šedesátých let podněty i z výrazně odlišných způsobů inscenačního ztvárnění. V pražském Národním divadle se projevovala snaha navázat na průbojné kreace Velké opery 5 . května, reprezentované vizuálně osobitými koncepcemi tandemů Václav Kašlík - Josef Svoboda a Ladislav 
Štros - Vladimír Nývlt. Jak Kašlík, tak Štros se vưči Felsensteinovi vymezovali de facto negativně. Kašlík sice nepopíral význam Felsensteinovy metody, kterou spolu s poetikou Wielanda Wagnera a stylem Velké opery 5. května považoval za nejprůbojnější tendence v operním divadle po roce 1945. S Felsensteinem se ale rozcházel už jen v základním přístupu ke ztvárnění opery na scéně, spočívajícím v akcentaci výtvarné složky, kterou upřednostňoval před hereckou složkou ${ }^{63}$ Ladislav Štros, ač byl u Felsensteina několik měsíců na stáži, se výslovně bránil tomu, že by od něho „něco odkoukal“. Jedinou inspirací, kterou přiznával, měla být důkladná a intenzivní práce se zpěvákem. Štros však vždycky usiloval o nepsychologické herectví, čímž se vymykal i tehdejší praxi na českých operních scénách: „Na rozdil od Felsensteina jsem nikdy neusiloval o realistický ba naturalistický styl opery. Naopak jsem směroval k imaginativnimu odlehčeni, $k$ metafoře. " 64

Pokud byl tedy Felsenstein v nějakém ohledu vyzdvihován a dáván bezvýhradně za vzor, pak právě v tom, jak důkladně pracoval s operním zpěvákem a dokázal ho získat pro svou uměleckou vizi. Zmiňme v závěru zkušenosti několika českých operních umělců, kteří měli možnost s Felsensteinem úzce spolupracovat. Když po letech zavzpomínala na své dojmy ze stáže v berlínské Komické opeře režisérka Alena Vaňáková, první, co si vybavila, bylo právě ono pověstné felsensteinovské precizní herectví - režijní maximalismus, dovedený v práci se zpěvákem do krajnosti. ${ }^{65}$ Posedlost detailně vypracovaným herectvím, zvyk zkoušet větu za větou, frázi za frází, takt po taktu tak dlouho, dokud výsledek Felsenstein nepovažoval za jednoznačně přesvědčivý, potvrzuje také Jana Smítková, která vystupovala ve dvou jeho inscenacích. Tato představitelka Káti Kabanové v Herzově inscenaci z roku 1972 připomněla ještě další důležitý aspekt Felsensteinovy inscenační práce. Felsenstein podle ní vždycky hledal zpěváka, který nejenže se dokázal po herecké stránce „zmocnit“ jím představované postavy, ale zároveň přesně odpovídal jejímu typu. ${ }^{66}$ Klemens Słowioczek zpíval osm let Figara ve Felsensteinově poslední inscenaci (Figarova svatba) a jak se zmínil, počínání tohoto režiséra na scéně nikdy nepocitoval jako realismus. Z působení v Komické opeře v daném období si odnesl poznatek, že Felsenstein byl mimořádný tím, že dokázal dovést zpěváka do stavu nejvyššího možného porozumění tomu, co zpívá a jak v dané situaci jedná. Podobnou zkušenost pak už Słowioczek učinil pouze sporadicky. ${ }^{67}$

Právě ve schopnosti přivést interpreta ke smyslu díla a pomoci mu nalézt způsob vyjádření, jímž by se toto dílo pro diváka stalo důvěrně blízkým, spočívá hlavní přínos Waltera Felsensteina opernímu divadlu. Na druhé straně je ale třeba vést v patrnosti,

63 Ve své autobiografii se nazývá „režisérem - inscenátorem“, který vidí hudbu nejprve v obrazech a teprve poté ji překládá do hereckého pohybu a gesta. Srov. KAŠLíK, op. cit., s. 58.

64 Srov. ŠTROS, Ladislav, Pavel PETRÁNĚK a Daniel JÄGER. Má cesta operou. Národní divadlo, Praha 2006, s. 83 .

65 Rozhovor Heleny SPURNÉ s Alenou VAŇÁKOVOU ze září 2016 (audionahrávka v soukromém archivu HS).

66 Rozhovor Heleny SPURNÉ s Janou SMÍTKOVOU z listopadu 2016 (audionahrávka v soukromém archivu HS).

67 Rozhovor Heleny SPURNÉ s Klemensem SŁOWIOCZKEM z listopadu 2016 (audionahrávka v soukromém archivu HS). 
že styl, jímž Felsenstein partituru a její významy na scéně vyjadřoval, může být vnímán jen jako jeden z možných inscenačních př́istupů. Jakkoli se to zdá málo pravděpodobné, soudobému opernímu divadlu Felsenstein konvenuje tím, že dílo domýšlel a interpretoval v kontaktu s prŕtomnou dobou, s jejími projevy sociálními i kulturně estetickými. Od řady dnešních režisérů se nepochybně lišil úsilím o dosažení umělecké dokonalosti a integrity, k níž nemálo přispíval „vylepšováním“ původního díla, veden představou klasického dramatu s pravidelnou stavbou a psychologicky jednajícími postavami. Současné divadlo - přinejmenším v německé kulturní oblasti - však směřuje spíše k odhalování rozporů uvnitř díla samého, k nastolování protikladů a ke konfrontaci s inscenační tradicí, která slouží jako vehikulum společenské kritiky a politické reflexe moderního světa.

Studie vznikla v rámci grantového projektu GA15-06548S „Generace Miloše Wasserbauera a progresivní dramaturgie v opeře Státního divadla v Brně“.

\section{Bibliography}

BAJER, Jiří. Achillova pata Komické opery? Divadelni noviny, roč. 5 (1962), č. 23, s. 8. BOR, Vladimír. Bystrouška v berlínském podání. Lidová demokracie, 31. 5. 1962.

BOR, Vladimír. Komická opera zahájila Othellem. Lidová demokracie, 26. 5. 1962.

BROŽOVSKÁ, Jarmila. Felsensteinovy inscenace v Praze. Divadlo, roč. 7 (1956), č. 7, s. 597-601.

BROŽOVSKÁ, Jarmila. Zápas o pravdu v opeře. Divadlo, roč. 10 (1959), č. 10, s. 780-788.

BROŽOVSKÁ, Jarmila. Komická opera a my. Kultura, roč. VI (1962), č. 22, s. 4.

BROŽOVSKÁ, Jarmila. O současné operní inscenaci. Mladá fronta, 21. 11. 1965.

BROŽOVSKÁ, Jarmila. Musiktheater - současné operní divadlo? Divadlo, roč. 17 (1966), č. 2, s. $76-78$.

BURIAN, Karel Vladimír. Walter Felsenstein. Supraphon, Praha 1979.

dt. W. Felsenstein v Praze. Večerni Praha, 14. 5. 1956.

FELSENSTEIN, Walter. Příspevěk k diskusi o hudebním divadle. Divadlo, roč. 7 (1956), č. 7 , s. 602-603.

FELSENSTEIN, Walter. K interpretaci Janáčkových oper. Hudebni rozhledy, roč. 11 (1958), č. 22, s. 925.

FELSENSTEIN, Walter a Siegfried MELCHINGER. Hudobné divadlo. Štátne hudobné vydavatel'stvo, Bratislava 1964.

FELSENSTEIN, Walter a Götz FRIEDRICH a Joachim HERZ. Musiktheater. Beiträge zur Methodik und zu Inszenierungs-Konzeptionen (hg. von Stephan Stompor). Philipp Reclam, Leipzig 1970.

FELSENSTEIN, Walter. Schriften zum Musiktheater (hg. von Stephan Stompor). Henschel, Berlin 1976.

FELSENSTEIN, Walter. Theater. Gespräche, Briefe, Dokumente (hg. von Ilse Kobán). Edition Hentrich, Berlin 1991.

HAVLÍČKOVÁ KYSOVÁ, Šárka. Teoretické dílo Miloše Wasserbauera v kontextu dobového myšlení o operní inscenační tvorbě. Theatralia, roč. 20 (2017), č. 2, s. 69-95.

HAVLÍČKOVÁ KYSOVÁ, Šárka a Helena SPURNÁ. Realismus hudebního divadla Waltera Felsensteina - pravda, nebo mýtus? Theatralia, roč. 20 (2017), č. 1, s. 88-121. 
HERBORT, Heinz Josef. Wie „real“ ist das realistische Musiktheater? Jahrbuch der Komischen Oper Berlin 1966/67. Henschel, Berlin 1967, s. 191-194.

HERRMANNOVÁ, Eva a Vladimír LÉBL. Janáček, Felsenstein a Komická opera, Literárni noviny, roč. XI (1962), č. 23, s. 1 a 3.

HINTZE, Werner, Clemens RISI a Robert SOLLICH (Hrsg.). Realistisches Musiktheater. Walter Felsenstein: Geschichte, Erben, Gegenpositionen. Theater der Zeit (Recherchen 51), Berlin 2008.

KAŠLÍK, Václav. Jak jsem dělal operu. Panton, Praha 1987.

KEHRMANN, Boris. Vom Expressionismus zum verordneten „Realistischen Musiktheater“. Walter Felsenstein - Eine dokumentarische Biographie 1901 bis 1951. [Dresdner Schriften zur Musik. Hochschule für Musik Carl Maria von Weber Dresden, hg. von Matthias Herrmann, Bd. 3, 2 Teile]. Tactum, Marburg 2015.

KOTEK, Josef. Berlínská komická opera se představila v Praze. Mladá fronta, 24. 5. 1956.

KRISTI, Grigori W. Stanislawskis Weg zur Oper. Henschel, Berlin 1954.

KRIŠKA, Branislav. Režisér - autorita - tradícia. Hudobný život, roč. II (1970), č. 21 (6. 11. 1970), s. 1 a 8.

Leoš Janáček a soudobá hudba. Sborník z Mezinárodního hudebně vědeckého kongresu v Brně 1958. Panton, Praha 1963.

OTTO, Werner (red.). Die Komische Oper 1947-1954. Henschel, Berlin 1954.

PACLT, Jaromír. Felsensteinův Othello. Divadelni noviny, roč. 3 (1959/60), č. 4, s. 8.

PEČMAN, Rudolf. Felsensteinova koncepce opery. Host do domu, roč. IX (1962), č. 7, s. 323.

PEČMAN, Rudolf. O opeře s Milošem Wasserbauerem. Hudebni rozhledy, roč. 17 (1964), s. 185-187.

PEČMAN, Rudolf. Hudební divadlo k diskusi. Věda a život, 1966, č. 3, s. 191-192.

PEČMAN, Rudolf. Principy hudebního divadla a interpretační styl oper Janáčkových (Kritická retrospektiva jako podnět k zamyšlení). Program Státního divadla Brno, roč. XLVII (1977), č. 9, s. $315-320$.

PROCHÁZKA, Jaroslav. Dvakrát s Waltrem Felsensteinem. Divadelni noviny, roč. 5 (1962), č. $16-$ 17, s. 8.

RIHA, Carl. Zur Interpretation der „Verkauften Braut“. Jahrbuch der Komischen Oper Berlin 1966/67. Henschel, Berlin 1967, s. 207-215.

STANISLAVSKIJ, Konstantin Sergejevič. K. S. Stanislavskij o operním divadle. Sovětské divadlo, roč. IV (1954), č. 3, s. 295-301.

SYCHRA, Antonín. Nad tvorbou W. Felsensteina. Tvorba, roč. 27 (1962), č. 23 (4. 7. 1962), s. 538539.

ŠALDOVÁ, Lenka. Česká operni režie v šedesátých letech 20. století. Disertační práce, Filozofická fakulta UK, Praha 2005.

ŠEFL, Vladimír. Komická opera a opera. Hudebni rozhledy, roč. 15 (1962), č. 13, s. 540-542.

ŠTROS, Ladislav. Jak jsem v Praze inscenoval Janáčka. Opera. Informační zdroj SOP (1995/96), č. 3 (26), s. 23-24.

ŠTROS, Ladislav, Pavel PETRÁNĚK a Daniel JÄGER. Má cesta operou. Národní divadlo, Praha 2006.

TONCROVÁ, Dana. Miloš Wasserbauer a jeho hledáni realistické scénické interpretace v opeře (Tvorba Miloše Wasserbauera ve Státním divadle Brno v letech 1958-1970). Diplomová práce, Filozofická fakulta MU v Brně, 2000.

VOJTĚCH, Ivan (šifra iv). Dilema operního herectví. Felsenstein 1962. Divadlo, roč. 13 (1962), č. 7, s. 52-53.

WASSERBAUER, Miloš. Princip realistické scénické interpretace v opeře. Divadlo, roč. 8 (1957), Č. 3, s. 211-214. 